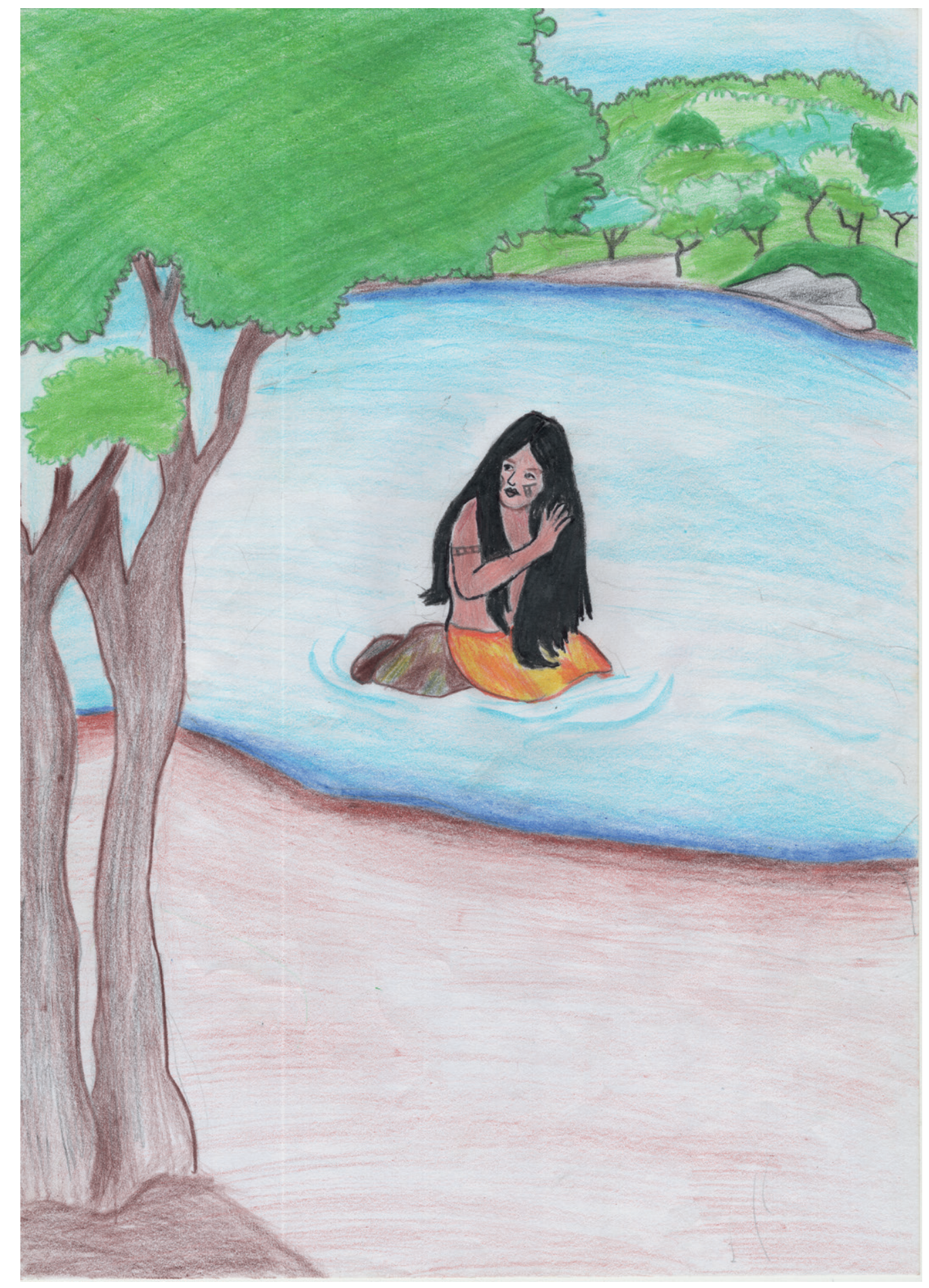




\section{Ooya Txtxoso}

Abdon dos Santos

I kone thliman khia, i ho khiakahe yake fekhlaxkya sato eethe susoma txfalte. Nema nekawde ke i satkhalaykya nokase de yaathelha ke. Nema i tiaman hle, i ho khiaka i thokhethanelha sato nanisene sato lay, tha tole. Thoosedey, tatxhante, tha lkinte thooman, djo khiaka tha tole. Se takewa tsote thookhiakke. Neknay hle, fekoman hle, ya nankya owa ooya teeke txay fthone ewlidjonkya taka salkinte. Nema i tookhethane ke i neka hle de. "- I sa, kane, efnixi txay fthone kinse!” Nema hle: “- Unke, yaadedwa? A winkya teka, mahe?” “- I wiidode. Kane! Fnite!” E fniman hle txhutsa txay sate ooya teeke. Ama ekhde? Txhuuuuu... Nema hle: "- Senenkya hesa, ka! Awtsa txayhe ooya txtxoso, ooya tookhethane, tha nese. Awtosa, ama kefe?"

Newde hle yooka hle de isa itho tole nede I tookhethane nanisene sato tole lahele fulikha tuy, ama kefe? Nema ufa ya txman ta i tookhethane nanisene ya kuldjohe fdate fulikha ke. Sade. "- Exideytowa tha txinexi sato."

Nema yooka.

Ixtola senenkya lulnite.

Yooka hle. Ufa ya tximan hle, itsa tkooka hle de fowa dotkane ooya teeke. “- Kanin!”

Teeke totdowa fthowa kexa, ooya teeke. Nema ta sakhoho nolneman hle txay kui ke. Ta futxkya txay fthone ooya teeke. Neho teeke hle txidjo nendowa. Nema ta sa tkhatxi fdaka hle de txhua fowa sato teeke, tkodowa etwa fthowanay teeke tkookake txidjo futxti.

Nema e tkhatxima hle, ta nelha hle de yatookhethane nanisene sato: "- Ta i ufa, ooya teeke. I tkhatxi yeekhdedekase. Nema ufa teeke txay fthone kui ke futxkyase de."

Nema nekdey itookhethane nanisene sato neka: “ $\neg-$ Ooya txtxososehe, kawa, a kui ke futxidonkyase."

Newdehle ya tkya hle de ya txidjo sato lay.

Ya tximan hle i tookhethane nanisene ekhaykya hle de. Khlokman hle ta ya tosnewka hle de ya khofle sa tole. Sakman lelnete ya xkya hle sa tole, ya keete.

Newde ta sehe sdowa txhone. Etxkya hle de dokexkya fthone ke txhua sehe 
sdowa etxhuante. Nekadjoke take sexne khante. Nekadjoke yasdey ta koka hle. "- Wa sa athe xinexitowa!" Ya keesesde, ya txkya hle de sa athe xnete. Nema wake nedwa dehe ooke fulinse de dehe, awtsa txay, awtsa txaine, ya fenkhettotwalha sato exine khiaka.

Fathowa nelha khiaka, setso fathowa sa thwa holhaka neso te, nese thwalha khiakke noman khiaka foente txidjo sato de teetxonelha khiaka de. "Totte tetdowa khofean? Ama ekhde? Nema eekhde. Txiane."

Etxtxosolhane, fowa txtxosone, fowa txtxoso, fowa txtxososehe. Setsonkya fthone yeexineka elka otxhaytowa ke, ama kefe? Setsonkya fthone owasehe. Tkanewa, nelha kakahe.

Nema tha de fathone edooka takanema, theehenkya, theehenkya. Theeheman hle thooman efnite, thooya khiaka. Newdehle setso sato noman hle satxfonte tha nankya thooya. Nema thooka hle de setso sato xiti ke neso takahe thooya. "Yooxi take!"

Thooman fle, theehenkya kaske. Theehema lixino ke hle thooman hle efinite khoxkya txti. Kaske thooya talhaka. Nema thooka hle de exite: "- Yooka hle ehente kaske."

Thooman, kahne, theehente wintooke thooman hle efnite kaske taka thooya.

Nekke tha sa tosneka hle itfetkwa note ufa, ta te saathekyante, tolelha nete, khokhilhate, tha fdalhate. Nema hle: "- Atelha saathekyankya teka awahelha fdalhate!"

Theeheman hle, etkhatxdjotkya hle, que é awa fowa ethayo, tha nese. Ama ekhde? Newke sasalha tatalhaka ufa. Nema etkha taka hle de, mãe Luzia, tha neseke etkha.

Nema neka kte de i nese wake neka senenkyalhahe. Yasa xinedwa dmaneho, ya tokhettotwalha sato exinedwa khia, ama ekhde?

Kaske awtsa exinedwa.

I tookhethane nokahe sehe sdowa fdate.

Nemahle txiane ke txay fthone teka ethe tkhatxi:

“- Aaaaaa!"

Nema, teetso!

Nema satkhamatilha ta neka:

“- Ya tixi! Txiane etsatsolha netkadeka. Ama kefe?"

Que é i neskyate: awde hle nekawde ke tha ikeyni.

Nema awatsa ta ewlisiane.

Nemahle ta ewlisianeman khia e ho khiaka sakfalte, ta satheekyante. 
Nema ethoke ta khefkya ke eninkya ke awtsa txidjone sewasa ate, teetxhinke kfale nanika. Ta olkyaka hle take esete tolelha ke. Nemay etookhethane nanisenelha ta txineka hle de: "- Ama kefe?"

Nema nekawde etkhatxi, yake ankyalha de theexinedwa khia awtsa txidjone sewasa tha kefe khiaka. Nema nekawdeke sane, sankya de awa ooya teeke txidjo edowa sato de sewasawa. Tha sa teefalha khaka, sewasa. Sankya lahele de fowane fthone sethxinke kfale flidonho. Txfalese de kikaksa. Neho iio, tha nese awa! Tonkyatke khetkya kte eflili ke se kfalse ke? Yaathe yeekhdedeka, ikfalse de kika, hum! Se kfalese ke se kfafman flilia, tonkya flilia khetkya? Flilia, anhan. Flilia tododonkya efahankya, nema tha txhinke kfale flidone. Fdesea kui tsasa neso lahe yasa eydonkya se txhinke kfale flidone. Awtsa txidjone sewasa etxhinke dmaneka. Nehodenkya tefadonkya, ama kefe?

Nema ooke, ya khletxhakahe de ooke toonawa ya tixte, ama ekhde? 


\section{A Mãe D’água}

Abdon dos Santos

Quando eu era menino, eu andava com os velhos, escutando as conversas deles. Assim, eu pensava muito na nossa língua. Quando cresci, eu andava com as minhas avós também, com elas. Por onde quer que elas andassem, pegando lenha, quando elas iam tomar banho, eu ia com elas. Porque elas iam lavar roupa. Numa dessas vezes, quando nós demos fé, nós vimos dentro d'água uma mulher de cabelos compridos tomando banho. Aí eu já disse à minha avó: “-Minha mãe, cuidado, olhe uma mulher sentada!” Então: “- Onde, menino? Você está mentindo, não é?” “- Não é mentira. Vá! Olhe!” Quando ela olhou, aquela mulher se jogou dentro d'água. Sabe? Tchuuuuu... Então: “- Que coisa, filho! Essa mulher é a Mãe D’água, Mãe D’água, como dizem. Aquela, está ouvindo?”

Depois nós fomos com meus parentes e com minhas avós também para o rio, está ouvindo? Então quando nós chegamos lá minha mãe fez a gente ir procurar o que comer no rio. É verdade. “- Chame seus irmãos!”

Então nós fomos.

É uma história curta.

Nós fomos. Quando chegamos lá, meu parente entrou no meio da pedra dentro da água. Foi difícil para ele sair. "- Cuidado!”

Dentro estava um pouco seco, dentro da água. Então ele passou a mão no peito de uma mulher. Ele pegou em uma mulher dentro d'água. Ali dentro havia muito peixe. Aí ele saiu procurando aqueles que entram nas pedras, os que entraram na craibeira, para pegar esses peixes. Aí quando ele saiu, ele disse a nossas avós: “- Eu estava lá dentro d'água. Eu não sei como eu saí. Lá dentro eu peguei no peito de uma mulher.”

Aí minha avó disse de novo: “- Foi a Mãe D’água, meu filho, a que você pegou no peito!"

Daí nós voltamos com os nossos peixes.

Quando nós chegamos, minha avó já ia fazer comida. Quando ela cozinhava, ela nos juntava para comer com ela. Quando estávamos juntos nós ficávamos alegres com ela, comendo. Depois ela trazia imbu verde. Ela chegava com aquele imbu verde espremido no prato, depois ela botava açúcar em cima. Depois ela 
dava a todos nós. “- Adocem a boca de vocês!” Depois que nós comíamos, nós ficávamos com a boca adoçada.

Então eu estou contando para vocês aqui a história do rio, dessa mulher, essa mulher, que os nossos antepassados contavam.

Um índio contava, um índio gostava de andar por conta dela, dizia que era porque gostava quando ia pescar e trazia muito peixe. "- O que ele fez para isso? Você sabe?"

Então sabem. Embuzeiro.

Havia uma índia, havia uma índia na serra, a índia da serra, a índia que era da serra. Era uma índia, os brancos desvalorizam nossas histórias, não entendem, está ouvindo? Que essa era uma índia. Duas, melhor dizendo.

Então, quando uma delas morreu, eles a enterraram, eles a enterraram. Quando eles enterraram, foram olhar, estava aberto. Depois disso, os índios foram caçar e eles viram a cova aberta. Aí eles foram com outros índios e a cova estava aberta. "- Vamos até lá!”

Quando foram lá, eles a enterraram de novo. Três dias depois que eles enterraram, quando eles foram tirar palha, eles foram olhar. Estava aberto de novo. Então eles disseram: "- Vamos enterrá-la de novo.”

Quando eles foram, disseram, enterrar, e quando foram olhar de novo a cova estava aberta.

Por isso, eles se juntaram, meus antepassados, para eles irem lá, falar com ela, fazer um toré para agradá-la, para emocioná-la. Disseram: “- Nós viemos falar com você.”

Quando eles a enterraram, ela saiu, que é aquela da serra dos cavalos, que eles disseram. Sabe? Daí o corpo dela está lá. Então a cabeça dela está lá, mãe Luzia, porque que eles dizem, a cabeça dela.

Então é isso que eu estou contando a vocês, são essas histórias. Nós contamos a beleza da história que nossos antepassados contavam, sabe?

De novo, essa não foi contada.

Minha mãe foi procurar quixaba.

Aí do imbuzeiro saiu a voz de uma mulher:

“-Aaaaaa!"

A voz dela saiu.

Aí o camarada dela disse:

“- Vamos voltar! A índia dona das frutas não quer que a gente pegue."

Que é o que estou dizendo: de tudo eles me ensinaram. 
Então esta era moça.

Quando ela ficou moça, ela andava ouvindo e conversando na língua.

Aí ela escutou um cântico parecido com o esse cântico da mulher da água, uma voz parecida. Ela teve vontade de dançar o toré. Nisso, a avó dela já a chamou: "- Está ouvindo?"

É por isso que eu sei de tudo, nossas histórias que eles contavam dessa Mãe D’água que tem uma voz muito bela que eles escutavam. Então, porque tudo isso existe, existe esse lugar dentro d'água que os peixes andaram com seu fôlego. Eles procuram cama para dormir com seu fôlego. Tem também uma voz limpa que escutamos na serra. Saiu do meu sentido. Esse não, que eles dizem isso. E como é que se chama o que ouvimos de noite? Em Yaathe eu não sei dizer, saiu. Aquilo que a gente ouve de noite quando dorme, como é que se chama? Grilo, sim. Quando assamos grilo para comer, aí a voz fica limpa. Peito de sapo também melhora a voz. A voz daquela Mãe D’Água é bela. Ela come de tudo. Está ouvindo? Agora vamos cantar aqui algo para irmos embora, certo? 


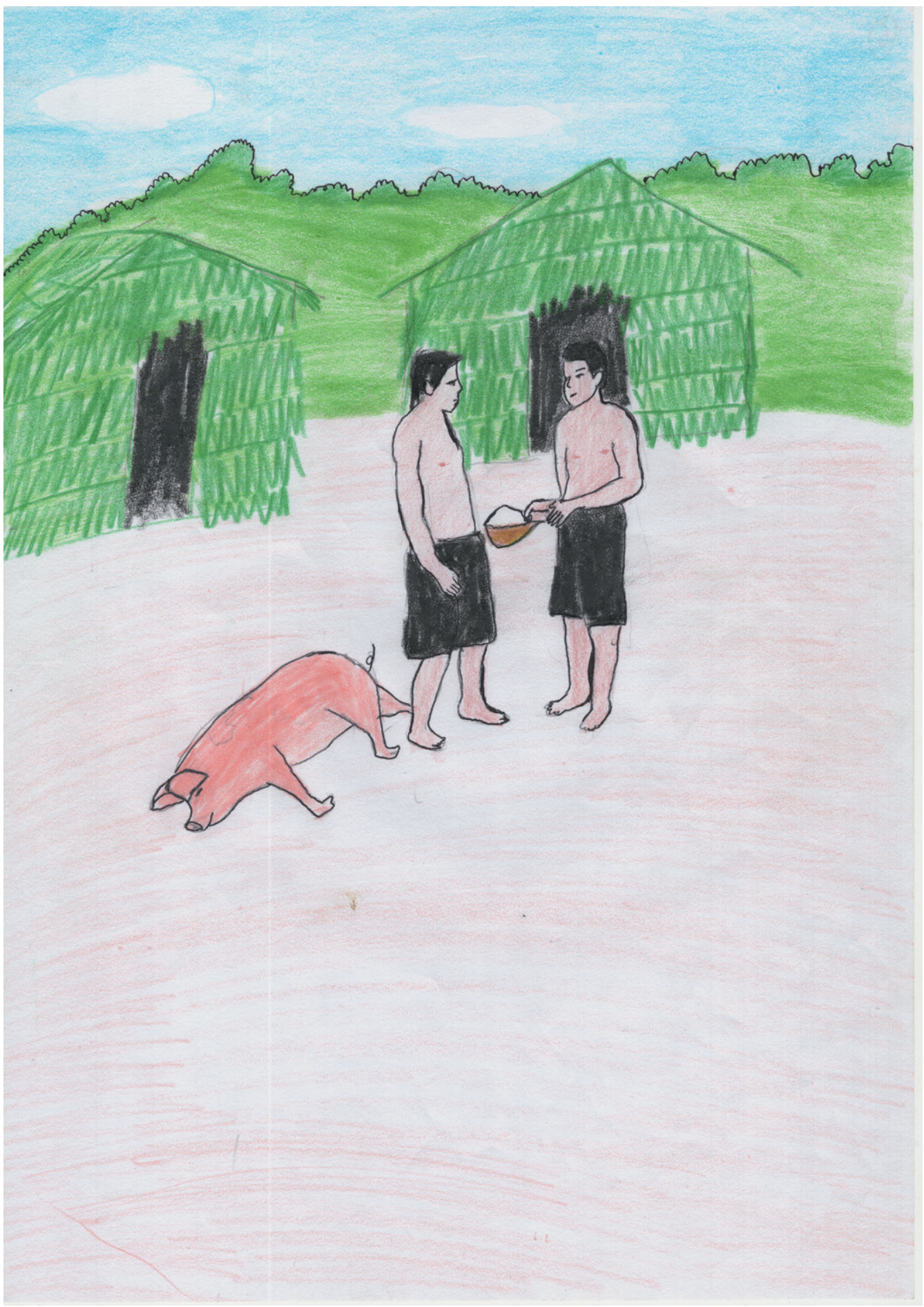




\section{Mother Water}

Abdon dos Santos

When I was a boy, I walked with the ancestry, listening to their conversations. So, I thought a lot about our language. When I grew up, I started to walk more often with my grandparents. Whatever they were doing - picking up branches, swimming on the lake -, wherever they went, I went with them. They used to bath in the woods. One day, we saw a woman with long hair bathing in the water. Then I said to my grandmother:

- Mom, look at that woman sitting there!

- Where, boy? You are lying!

- It's true! Look! I'm not lying.

When she looked up, the woman threw herself into the water.

- What is that thing, son? This woman is the woman water, "mother water", as they say.

Are you following me? Then we went to the riverwith my parents and my grandparents. When we got there, my mother asked us to find something to eat on the river. It is true.

- Call your brothers!

So there we went.

It's a short story.

There we went. When we got there, my brother went to a stone that was in the middle of the river. It was very hard for him to geat out of there.

- Be careful!

The river was a little bit low. He put his hand on the water and touched something that felt like a woman's breast. He touched a woman inside the water. There was a lot of fish there. He started to look for the ones that went to the rocks; he wanted to catch these fish. When he left, he told our grandmothers:

- I was there in the river. I don't know how I got out of it. While I was in there, I touched something that felt like a woman's breast.

Then my grandmother said again:

- You touched Mother Water's breast; that's what you touched. 
Then we all came back with our fish.

When we arrived, my grandmother was about to make food. When she cooked, she gathered everone together to eat with her. When we were together we were happy with it, eating with her. Then she brought green imbu. She came with that squeezed green imbu on the plate, then she would put some sugar on top. Then she would give us all a little bit of that treat

- Sweeten your mouth!

After we ate that, we all had with sweeten mouth.

So I'm telling you here the story of the river, of this woman, a story that was told by many of our ancestors.

There was an indian who liked to walk around her, because he liked when he went fishing and could bring home a lot of fish.

- How did he do that? Do you know?

So they know. Imbu tree.

There was an indian woman; once there was an indian woman in the mountains, the mountain india, the indian woman who was the mountain. She was an indian. White people devalue our stories; they don't understand them. They don't say it was an indian. Actually, two indians.

When one of them died, they buried her, they buried her. After they buried her, they went there to look at the burial place; it was open. When the indians went hunting, they saw the open grave. Then they came back there with other indians; the pit was open.

- Let's go there!

When they got there, they buried the woman again. Three days after they buried her, after they were collecting straws, they went back to the burial site. It was open again. Then they said:

- Let's bury her again.

Then there thet went again to bury the woman, that's what they told us. When they returned to see the burial site, it was again open.

So my ancestors gathered together and went there to talk to her, to make a toré to please her, to thrill her. They said:

- We came here to talk to you.

When they buried her, she came out. I'm talking about that one from Serra dos Cavalos. Her body is there. Her head is there. Mother Luzia. That's what they say. Her head.

So that's that. I'm telling you these stories. We tell you the beautiful stories that our ancestors told us, you know? 
Alas, this has not been told so far.

My mother went out to look for quixaba.

She then heard a woman's voice from the imbu tree:

- Aaaaaa!

That's her voice that came out from the tree

Then her partner said:

- Let's go back! The indian who owns the fruits doesn't want us to pick them.

That's what I'm saying: everything I know, they taught me.

So this one was young woman.

When she was young, she listened and talked in the language all the time.

Then she heard a song similar to the song that the mother water sings; a similar voice. She wanted to dance toré. Meanwhile, her grandmother called her:

- Do you hear that?

That's why I know everything, the stories they told about mother water, who has a very beautiful voice, so they said they could hear. So this is why all these things exist. There is this place in the water where the fish can walk with their own breath. They look for a bed, so they can sleep there. There is also this clear voice that we can hear in the mountains. This came out of my senses. And how do you call what we hear at night? I don't know how to say it in Yaathe. That thing we hear in the evenng, when we are sleeping; how is it called? Cricket, yes. When we bake cricket to eat, our voice gets cleaner. Frog's chest also improves the voice. That mother water's voice is beautiful. She eats everything.

Now let's sing something so I can leave, ok? 